\title{
Okul Yöneticilerinin Benlik Saygısı Düzeyleri İle Kişisel Ínisiyatif Alma Durumları Arasındaki İlişki*
}

\section{The Relationship Between Self-Esteem Levels Of School Managers And Taking Personal Initiative}

\author{
Erhan SEVİL**, Tuncer BÜLBÜL***
}

\begin{abstract}
Öz: Bu araştırmada okul yöneticilerinin benlik saygısı düzeyleri ile kişisel inisiyatif alma durumları arasındaki ilişkinin belirlenmesi amaçlanmıştır. Araştırmada şu sorulara yanıt aranmıştır: Okul müdürlerinin benlik saygılarına ilişkin algıları ve kişisel inisiyatif alma durumları nasıldır? Okul müdürlerinin algılarına göre benlik saygısı düzeyleri ve kişisel inisiyatif alma durumları; eğitim durumlarına, mesleki hizmet sürelerine, yaşlarına, çalıştıkları kurumların bulunduğu yerleşim biriminin türüne, farklılık göstermekte midir? Okul müdürlerinin benlik saygısı düzeyleri ile kişisel inisiyatif alma durumları arasında ilişki var mıdır? Okul müdürlerinin benlik saygıları kişisel inisiyatif alma durumlarının yordayıcısı mıdır? $\mathrm{Bu}$ araştırma ilişkisel tarama modelindedir. Araştırmada örneklem alınmamış, evrenin tamamına ulaşılmaya çalışılmıştır. Araştırma kapsamında 2018-2019 eğitim öğretim y1lında, Edirne merkez ve ilçelerinde görev yapan devlet okullarından ilkokul, ortaokul ve liselerde görev yapan toplam 161 okul müdürüne ölçekler uygulanmıştır. Araştırmada Arıcak (1999) tarafindan geliştirilen "Arıcak Benlik Saygısı Ölçeği”" ile Akın (2012) tarafından geliştirilen "Okul Müdürlerinde Kişisel İnisiyatif Ölçme Aracı Okul Müdürü Formu" kullanılmıştır. Bu çalışmanın bulgularına göre okul yöneticilerinin benlik saygısı düzeylerinin ve kişisel inisiyatif alma durumlarının yüksek düzeyde; benlik saygısı düzeyleri ile kişisel inisiyatif alma durumları arasındaki ilişkinin tüm boyutlarda orta düzeyde ve pozitif yönlü olduğu görülmüştür. Çoklu regresyon analizi sonucuna göre benlik saygısı ölçeğinin benlik değeri, özgüven, depresif duygulanım, kendine yetme, başarma ve üretkenlik boyutlarının kişisel inisiyatif alma ölçeğinin kendiliğinden başlama boyutunun \% 44'ünü, proaktiflik boyutunun \% 47'sini, 1srarcılık boyutunun \% 42'sini yordadığı anlaşılmıştır. Araştırmanın sonuçlarına göre, okul müdürlerinin kişisel inisiyatif almada üst makamlarca daha fazla desteklenmesi önerilebilir. Yine okul müdürlerinin seçiminde benlik saygısı düzeylerinin de dikkate alınacağı bir model geliştirilebilir.
\end{abstract}

Anahtar Kelimeler: Benlik saygısı, kişisel inisiyatif, okul yöneticisi

\begin{abstract}
The aim of this study was to determine the relationship between school principals' self-esteem levels and personal initiative. In this research, what is the perception of school principals about their selfesteem and how to take personal initiative, self-esteem levels and taking personal initiative according to the perceptions of school principals; do they differ in terms of education, professional service period, age, type of settlement where the institutions they work for, is there a relationship between school principals' self-esteem levels and personal initiative, are school principals' self-esteem predictors of individual initiative questions were sought. This research is a relational survey model. The sample was not taken in the study and the whole universe was tried to be reached. Scales were applied to 161 school principals working in official primary, secondary and high schools in Edirne city center and districts in 2018-2019 academic year. Aricak Self-Esteem Scale developed by Arıcak (1999) and Okul Personal Initiative Measurement Tool School Principal Form "developed by Akın (2012) were used in the study. According to the findings of this study, the level of self-esteem and personal initiative of school administrators were high; The relationship between self-esteem levels and taking personal initiative was found to be moderate and positive in all dimensions. Multiple regression analysis revealed that the self-esteem scale dimensions

\footnotetext{
* Bu çalışma, ikinci yazarın danışmanlığında ilk yazarın Trakya Üniversitesi Sosyal Bilimler Enstitüsü Eğitim Bilimleri Anabilim Dalı Eğitim Yönetimi Teftişi Planlaması ve Ekonomisi Bilim Dalında 2019 yılında tamamladığı “Okul Yöneticilerinin Benlik Saygısı Düzeyleri İle Kişisel İnisiyatif Alma Durumları Arasındaki İlişki” adlı yüksek lisans tezinden üretilmiştir.

** Türkçe Öğretmeni, Edirne-Türkiye, ORCID: 0000-0002-4668-4474, e-posta: erhan-sevil@ hotmail.com

*** Prof. Dr. Trakya Üniversitesi, Eğitim Fakültesi, Edirne-Türkiye, ORCID: 0000-0001-6334-8264, e-posta: tuncerbulbul@trakya.edu.tr
} 
of self-worth based, self-esteem, depressive mood, self-sufficiency, achievement and productivity, $44 \%$ of self-starting size of the personal initiative to get the scale, $47 \%$ of proactivity size is predicted $42 \%$ of the insistence size. According to the results of the study, it can be suggested that school principals should be supported more by the higher authorities in taking personal initiative. Again, a model can be developed in which the self-esteem levels are taken into consideration in the selection of school principals.

Keywords: Self-Esteem, personal initiative, school administrator

\section{Giriş}

Kişisel inisiyatif, çalışanın rolünü yorumlamasını, örgüt yararına yeni amaçlar oluşturmasını ve bu amaçları 1srarcı bir biçimde uygulamasını ifade eden aktif bir performans kavramıdır (Akın, 2012). Çalışanın yenilik yaratmak için kendiliğinden harekete geçme durumu, işinde kendisinden beklenenden fazlasını yapma isteği, karşılaştığı zorluklarla mücadele isteği, engelleri aşma konusundaki kararlılığı, proaktif olma düzeyi, yeterlilikleri, karakter özellikleri bireylerin inisiyatif alma düzeyini belirler (Fay ve Frese, 2001). Kișisel inisiyatif davranış1 kendiliğinden başlama, proaktiflik ve ısrarcılık boyutlarından oluşmaktadır. Kendiliğinden başlama davranışı, bireyin açıkça belirtilmeksizin bir hedef izlediğini ifade eder. Ayrıca, izlenen hedef, işin resmi gerekliliklerinin yani iş tanımının ve açık iş rolünün ötesine geçer. İş tanımında istenenlere yanıt vermek kendiliğinden başlama davranışı olarak kabul edilemez (Fay ve Frese, 2000). Çalışanların kendilerini ve / veya çevrelerini etkilemek için yaptıkları ileriye yönelik eylem, proaktif davranış olarak tanımlanır. Proaktif davranışı tanımlamak için temel ölçüt, davranışın tanımlanmış rol veya tanımlanandan fazla bir rol olup olmadığı değil, çalışanın kendini veya çevreyi etkileyecek gelecekteki bir sonucu oluşturmayı öngörmesi, planlaması ve gerçekleştirmeye çalışıp çalışmadığıdır (Grant ve Ashford, 2008). Uzun vadeli hedefler uygulanmaya başlandığında genellikle yeni sorunlara, engellere ve gerilemelere yol açar. Çünkü iş iyileştirme için getirilen yeni öneriler, yeni yöntemlerle iş yapılmasılyla ve daha önce denenmemiș olmasıyla zorluklara sebep olacaktır. Örneğin, yönetici yeni fikri beğenmeyebilir veya başlangıçta yeni iş yöntemi doğru şekilde gerçekleştirilemeyebilir. Eğer bu zorlukların üstesinden gelinmezse veya engeller karşısında hemen vazgeçilirse, inisiyatiften bahsedilemez. $\mathrm{Bu}$ nedenle, inisiyatif, bu engellerin aktif ve sürekli olarak ele alınarak israrc1 olunmasının gerekliliğini ifade eder (Fay ve Frese, 2001). İnisiyatif, günümüz örgütlerinde giderek daha önemli hale gelmiştir ve bu örgütler, yenilikçi olan ve birilerinin onlara ne yapmaları gerektiğini söylemesini beklemeden harekete geçebilen çalışanlar istemektedir. Sonuç olarak, bu tür esneklik ve elastikiyet, örgütlerin yenilikçiliğinin artışını ve zorlukların üstesinden gelmelerini sağlamaktadır (Frese, 2009). Geleneksel sistemde okul müdürünün asli görevi, okulun amaçlarına ulaşabilmesi için gerekli olan kaynakların sağlanması, yönetim süreçleri ve işlevleri üzerine yoğunlaşmaktır. Günümüz okul müdürlerinin görev ve sorumlulukları, liderlik, iletişim, grup süreçleri, program geliştirme, öğretme ve öğrenme süreçleri, performans değerlendirme gibi birçok farklı başlıklar altında toplanmaktadır (Şişman ve Turan, 2004). Yani yöneticinin yerine getirmesi gereken roller ve görevler, rutin görevler yazışmalar, formaliteler, bürokratik iş ve işlemlerin çok ötesine taşmaktadır. Okul yöneticilerinin kendilerinden beklenilenleri yerine getirmeleri için kişisel inisiyatif almaları kaçınılmazdır. Okul yöneticileri rollerini yerine getirirken birçok faktörden etkilenmektedir. Bu faktörlerin başında da kendilerine ilişkin algıları gelmektedir. Bireyin bu rollere ilişkin olarak kendini nasıl gördüğünü içeren kavram benlik kavramıdır (Güngör, 1989). Bireyin kişiliği ile rollerine ilişkin algısı benlik kavramının kapsamındayken, bu algının derecesi benlik saygısı ile ifade edilmektedir. Benlik saygısı yüksek bireyler, olaylara başarılı olma ve insanlara iyi karşılanma beklentisi ile yaklaşırlar. Olumlu değerlendirmelere sahip bireyler kendi alg1 ve yargılarına güvenirler. Çaba gösterdiklerinde sorunlarını çözebileceklerine inanırlar. Sosyal ilişkilerinde daha etkin ve girişimcidirler. Düşük benlik saygısına sahip bireyler ise kendilerine güvenmez, farklı fikirler ortaya koymaktan çekinirler. Sosyal ilişkileri zayıftır, kişilerle iletiş̧imde katılımcı olmaktan ziyade dinleyici olarak yer alırlar (Coopersmith, 1967). Bu bakımdan okul yöneticilerinin yüksek benlik saygısına sahip olmaları beklenebilir. Çünkü okul müdürü, okulun amaçlarını gerçekleştirecek, yapısını yaşatacak ve havasını koruyacak iç öğelerin lideri olmak zorundadır (Bursalıoğlu, 
1991). Kişisel inisiyatif davranışı bireyin kendisinin başlattığı ve devam ettirdiği bir davranış olması sebebiyle bireyin kendine ilişkin algılarının yani benlik saygılarının düzeyi ile ilişkilidir denebilir. Başka bir deyişle benlik saygısı yüksek olan okul yöneticilerinin kişisel inisiyatif alma konusunda örgütlerine daha fazla katkı sunmaları beklenebilir.

\section{Benlik saygısı}

Benlik saygısı, kendini olduğundan aşağı ya da üstün görmeden kendinden memnun olma durumudur. Kendini değerli, olumlu, beğenilmeye ve sevilmeye değer bulmaktır. Benlik sayg1s1, kendini olduğu gibi kabullenmeyi, özüne güvenmeyi sağlayan olumlu bir ruh halidir (Yörükoğlu, 2000). Coopersmith (1967), benlik saygısının kavramsallaşmasını iki kısma ayırmıştır; öznel ifade ve davranışsal ifade. Birincisi, bireyin kendine ilişkin algısı ve kendini tanımlaması; ikincisi, dış gözlemciler için mevcut olan bireyin benlik saygısının davranışsal tezahürlerini ifade eder. Benlik saygısı, tam anlamıyla insanların kendilerine verdikleri değerin düzeyi ile tanımlanır. Benlik saygısı, gerçeklikten ziyade algıdır. Örneğin, kişinin akıllı ve çekici olup olmadığına dair inancına atıfta bulunur ve aslında kişinin gerçekten zeki ve çekici olup olmadığı hakkında bir şey söylemez. İnsanların inançları eylemlerini pek çok önemli şekilde şekillendirir ve bu eylemler sosyal çevrelerini ve çevrelerindeki insanların sosyal gerçeklerini şekillendirir (Baumeister, Campbell, Krugger ve Vohs, 2003).

Coopersmith'e (1967) göre benlik saygısının gelişmesine katkıda bulunan üç temel faktör vardır. Bunlar: 1. Başarı: Bireysel başarıları değerlendirmek için, bir kişinin doğrudan, duygusal kişilerarası ortamı, genel toplum standartlarından daha önemlidir. 2. Her bir birey için başarının filtreleneceği özel değerler ve beklentiler: Değer yargısına karar verirken kişisel normlar, grup normlarından daha az etkilidir. Buna karşıllk kişisel hedefler, daha genel standartlar ya da belirsiz gizli umutlardan ziyade kişisel beklentileri yansıtır. 3. Engeller (bireyin devalüasyona cevap verme şekli açısından): Bu öneriye göre, başarı geçmişi "son derece elverişli, doğrulanmış bir tutum" için yeterli değildir, fakat aynı zamanda tüm kişilerin mutlaka karşılaştığı stres ve gerginliklerin üstesinden gelmek için bir yetenek olarak gereklidir. Yüksek veya düşük benlik saygısı, bireyler üzerinde çeşitli etkiler yapabilir. Benlik saygısı düşük olan bireylerin çoğu başarılarının büyük bir bölümünü kendi kontrollerinin dışındaki etkenlere dayandırarak kendilerine olan güvenlerini ve gelecekte başarılı olma şanslarını azaltırlar. Ayrıca hata yaptıklarında veya başarısızlığa uğradıklarında bu durumu kendileri dışındaki nedenlerle açıklarlar ve başkalarından yardım istemede çekinik davranırlar. Benlik saygısı yüksek olanlar ise başarılarını büyük ölçüde kendi emekleri ve becerileri olarak görürler. Başarısızlık karşısında bırakmak yerine tekrar harekete geçerek motive olurlar (Yavuzer, 2003).

Okul yöneticisi, okulu etkileyen farklı etmenleri incelemek, okul çevre ilişkilerini düzenlemek, velilerle ve toplumun çıkar gruplarıyla ilişki kurmak zorundadır (Çelik, 2004). Okul yöneticilerinin okul içindeki ve dışındaki sosyal iletişimlerde başarılı olmalarında sosyal becerilerinin yüksek olması son derece önemlidir. Bu nedenle okul yöneticilerinin yüksek benlik saygısına sahip olmaları beklenebilir. Çünkü yüksek benlik saygısına sahip olan birey sosyal ilişkilerinde daha girişimci, daha güvenli ve daha atak olmaktadır (Kuzgun, 2002). Benlik saygısı olumlu sosyal davranışlara ve ruh sağlığına katkıda bulunmaktadır. Düşük benlik saygısı ise depresyon, intihar eğilimi, yeme bozuklukları ve kaygı bozuklukları ile saldırganlık ve madde kullanımı bozuklukları gibi birçok sosyal davranış problemine ve psikolojik rahatsızlıklara sebep olmaktadır (Mann, Hosman, Schaalma ve De Vries, 2004). Welch, Meideros ve Tate'ye (1982) göre; okul yöneticileri iş yerinde soyutlanmışlıkları, işin niteliği gereği programlanmamış etkinlikleri, sorunlu insan ilişkileri, sınırlı yetkileri ve özel konumları nedeniyle sürekli bir stres yaşamaktadırlar (Akt. Dönmez ve Güven, 2001). Bu nedenle okul yöneticilerinin yüksek benlik saygısına sahip olmaları onların stresle başa çıkmalarını kolaylaştıracak etmenlerden biri olabilir.

\section{Kişisel inisiyatif}

Kişisel inisiyatif, bir bireyin işe alım ve belirli bir işte resmi olarak gerekli olanın ötesine geçen aktif ve kendiliğinden başlangıç yaklaşımını benimsemesiyle sonuçlanan bir davranış 
sendromudur. Kișisel inisiyatif kurumun misyonu ile tutarlıdır, uzun vadeli bir odak noktası vardır, hedefe yöneliktir ve eylem odaklıdır, engeller ve gerileme karşısında 1srarcıdır, kendiliğinden başlar ve proaktiftir (Frese, Kring, Soose ve Zempel, 1996). Kişinin hedefine ulaşması için 1srarcı olması gereklidir; kişisel inisiyatif genellikle bir işlemin, bir yöntemin, bir görevin eklendiğini veya değiştirildiğini, bu değişikliklerin genellikle gerilemeleri ve zorlukları içerdiğini ifade eder (Fay, Frese ve Garst, 2007). Proaktiflik, uzun vadeli bir odağa sahip olmaktır ve bir sorunla veya firsatla karşılaşıncaya kadar beklemek değildir. Çalışmaya uzun vadeli odaklanma, bireyin gelecekteki şeyleri (yeni talepler, yeni ya da tekrarlanan sorunlar, ortaya çıkan firsatlar) dikkate almasını ve bunlar hakkında hazırlıklı olmasını sağlar. Böylece, sorunlar ve firsatlar beklenmektedir ve bireyler her an onlarla başa çıkmak için hazırdırlar (Fay ve Frese, 2001). Kendiliğinden başlama davranışı, bireyin açıç̧a belirtilmeksizin bir hedef izlediğini ifade eder. Ayrıca, izlenen hedef, işin resmi gerekliliklerinin yani iş tanımının ve açık iş rolünün ötesine geçer. İş tanımında istenenlere yanıt vermek kendiliğinden başlama davranışı olarak kabul edilemez (Fay ve Frese, 2000). Kișisel inisiyatif yakın ve uzak nedenler arasında farklılaşmaktadır. Kişilik ile bilgi, beceri ve yeterlikler uzak nedenlerdir. Yönelimler yakın neden iken çevresel destekler ise uzak ve yakın nedenlerin bileşimidir. Çevresel destekler, kişilik ile bilgi, beceri ve yeterlikler yönelimleri etkilerken, yönelimler ise kişisel inisiyatifi etkiler (Fay ve Frese, 2001).

Okul yöneticiliği "durağan" değil "devingen" bir iştir. Bu da okul yöneticisinin her an değişen yeni durumlara göre önlem almak ve uyum sağlamak zorunda olduğunu gösterir (Binbaşığlu, 1988). Bu durum okul yöneticisinin proaktif davranışlar sergilemesi gerektiği şeklinde yorumlanabilir. Değişen durumlara göre önlem almak, değişen duruma ilişkin öngörülü ve hazırlıklı olmayı sağlayacak hedefler belirlemeyi gerektirir. Dolayısıyla okul yöneticisi kendi hedeflerini gerçekleştirmeye çalışarak inisiyatif alacaktır. Okulda her şeyi bir kurala prosedüre bağlamak, personel arasında ast-üst ilişkilerini belirtip yakın denetim uygulamak, böylece de verim beklemek mümkün olmamaktadır (Balcı, 2000). Bürokrasi ve hiyerarşiye aşırı bağlılık, okul yöneticisinin günümüz okullarının beklenti ve ihtiyaçlarını karșılamada yetersiz kalmasına ve onu sadece söyleneni yerine getirmekle yükümlü olan pasif bir duruma getirmesine sebep olabilir. Oysa günümüz örgütleri çalışanlarının yüksek örgütsel vatandaşlık duygusu ile hareket ederek, örgütün amaçları ile uyumlu hedefler oluşturan, kendilerinden beklenen rol davranışlarının ötesine geçen, talimat olmaksızın kendiliğinden başlama davranışları göstermelerini yani kişisel inisiyatif almalarını beklemektedir (Frese, Kring, Soose ve Zempel, 1996). Okul yöneticileri günümüzde geleneksel rollerinden çok çeşitli ve değişik rollere sahiptir. Bu nedenle daha fazla mesleki bilgi ve birikime sahip olmaları, çevrelerine karşı daha duyarlı olmaları, daha fazla sorumluluk alarak okullarını geleceğe taşımaları gerekmektedir (Balyer, 2012). Rollerini pasif olarak değil aktif olarak icra etmeleri gerekmektir. Okul yöneticilerinin yönetimlerinin sonucunda elde ettikleri etkililik ve başarı durumları göz önüne alındığında birtakım farklılıklar taşıdıkları görülmektedir. Bu farklılıklarından birinin de kişisel inisiyatif alma olduğu düşünülmektedir.

Okul yöneticilerinin yüksek benlik saygısına sahip kişisel inisiyatif alan bireyler olmalarının, etkili okulların oluşturulmasında gerek bugün gerek gelecekte önemli olacağ 1 düşünülmektedir. Ancak alanyazın incelendiğinde okul yöneticilerinin benlik saygısı düzeylerini ve kişisel inisiyatif alma durumlarını konu edinen araştırmaların azlığ 1 dikkat çekmektedir. Okul yöneticilerinin benlik saygısı düzeyleri ile kişisel inisiyatif alma durumları arasındaki ilişki durumunu ortaya koyan çalışma ise bulunmamaktadır. Bu çalışmanın belirtilen problemin aydınlatılmasına da katkı sunabileceği düşünülmektedir.

Ortaya çıkan bu bilgiler ışı̆̆ında okul yöneticilerinin, benlik saygılarının düzeyi onların kurumlarında günün koşullarına uyum sağlayacak, tanımlanmış rollerine fazladan sunacakları katkıların yani alacakları kişisel inisiyatiflerin örgütün başarısı için önem arz edeceği düşünülmektedir. $\mathrm{Bu}$ nedenle okul yöneticilerinin kişisel inisiyatif alma durumlarına benlik saygısı düzeylerinin etkisinin ne düzeyde olduğunun açıklığa kavuşturulması önemlidir. $\mathrm{Bu}$ doğrultuda bu çalışmanın problemi; okul yöneticilerinin benlik saygısı düzeyleri ile kişisel 
inisiyatif alma durumları arasında nasıl bir ilişki olduğunu ortaya koymaktır. Araştırmanın genel amacı çerçevesinde, şu sorulara yanıt aranmaya çalışılacaktır:

1. Okul müdürlerinin benlik saygılarına ilişkin algıları ve kişisel inisiyatif alma durumları nasildir?

2. Okul müdürlerinin algılarına göre benlik saygısı düzeyleri ve kişisel inisiyatif alma durumları; eğitim durumlarına, mesleki hizmet sürelerine, yaşlarına, çalıştıkları kurumların bulunduğu yerleşim biriminin türüne, farklılık göstermekte midir?

3. Okul müdürlerinin benlik saygısı düzeyleri ile kişisel inisiyatif alma durumları arasında ilişki var mıdır?

4. Okul müdürlerinin benlik saygıları kişisel inisiyatif alma durumlarının yordayıcısı midır?

\section{Yöntem}

\section{Araştırmanın modeli}

Okul yöneticilerinin benlik saygısı düzeyleri ile kişisel inisiyatif alma durumları arasındaki ilişkiyi ortaya koymayı amaçlayan bu araştırmada ilişkisel tarama modeli kullanılmıştır. Tarama modelleri, geçmişte ya da halen var olan bir durumu var olduğu şekliyle betimlemeyi amaçlayan araştırma yaklaşımlarıdır (Karasar, 2008). Bu modelde değişkenler arasındaki ilişkiler, korelasyon ve regresyon gibi güçlü istatistiksel teknikler kullanılarak ortaya çıkartılmaktadır (Balc1, 2013).

\section{Çalışma grubu}

Araştırmanın evreni 2018-2019 eğitim-öğretim yılında Edirne il merkezi, Keşan, Uzunköprü, İpsala, Havsa, Enez, Süloğlu, Meriç ve Lalapaşa ilçelerinde Milli Eğitim Bakanlığı'na bağlı resmi ilkokul, ortaokul ve liselerde görev yapan 225 okul müdüründen oluşmaktadır. Araştırmada örneklem alınmamış evrenin tümüne ulaşılmaya çalışılmıştır. Araştırma kapsamında 210 okul müdürüne ölçek ulaştırılmış; geri dönen 170 ölçekten hatalı, eksik ve özensiz doldurulanlar çıkarıldıktan sonra okul müdürleri tarafindan doldurulmuş 161 ölçek formu veri çözümlemesi için değerlendirmeye alınmıştır.

\section{Veri toplama araçları}

Arıcak Benlik Saygısı Ölçeği: Bu araştırmada okul yöneticilerinin benlik saygısı düzeylerini ölçebilmek için Arıcak (1999) tarafindan geliştirilen "Arıcak Benlik Saygısı Ölçeği" kullanılmıştır. Ölçek, 5'li likert tipi derecelendirmeyle düzenlenmiş ve "tamamen katılıyorum", "katılıyorum", "kararsızım", "katılmıyorum" ve "hiç katılmıyorum" seçeneklerinden oluşmaktadır. Ölçekte 32 ifade bulunmaktadır. Ölçek, beş boyuttan oluşmaktadır. Bu boyutlar; benlik değeri, kendine güven, depresif duygulanım, kendine yetme, başarma ve üretkenlik şeklinde oluşturulmuştur.Ölçeğin Cronbach Alpha güvenirlik katsayısı hesaplanmış ve ölçeğin güvenirlik katsayıs1 .90 olarak bulunmuştur.

Araştırmacı tarafından ölçeğin iç tutarlılığının test edilmesi amacı ile Cronbach Alfa testi ve İki Yarı Güvenirlik analizi uygulanmıştır. Analiz sonuncunda 32 ifadeden oluşan Benlik Saygısı Ölçeğinin toplam Cronbach Alfa katsayısı 0.92, iki yarı güvenirliğine ilişkin değer 0.89 olarak bulunmuştur.

Okul Müdürlerinde Kişisel İnisiyatif Ölçme Aracı Okul Müdürü Formu: Bu araştırmada okul yöneticilerinin kişisel inisiyatif alma durumlarını ölçebilmek için Akın (2012) tarafından geliştirilen "Okul Müdürlerinde Kişisel İnisiyatif Ölçme Aracı Okul Müdürü Formu" kullanılmıştır. Ölçek, 5'li likert tipi derecelendirmeyle düzenlenmiş ve "tamamen katılıyorum", "büyük ölçüde katılıyorum", "orta düzeyde katılıyorum", "az katıllyorum" ve "hiç katılmıyorum" seçeneklerinden oluşmaktadır. Ölçekte 32 ifade bulunmaktadır. Ölçek üç boyuttan oluşmaktadır. Bu boyutlar; kendiliğinden başlama, proaktiflik ve 1srarcılık şeklindedir. 
Ölçeğin Cronbach Alpha güvenirlik katsayısı hesaplanmış ve ölçeğin güvenirlik katsayısı 0.89 olarak bulunmuştur.

Araştırmacı tarafından ölçeğin iç tutarlılığının test edilmesi amacı ile Cronbach Alfa testi ve İki Yarı Güvenirlik analizi uygulanmıştır. 32 ifadeden oluşan Okul Müdürlerinde Kişisel İnisiyatif Ölçme Aracının Cronbach Alfa katsayısı 0.96, iki yarı güvenirliğine ilişkin değer 0.93 olarak tespit edilmiştir.

\section{Verilerin analizi}

Veri analizinde, öncelikle, parametrik testlerin gerektirdiği temel varsayımlar incelenmiş̧ir. $\mathrm{Bu}$ doğrultuda, verilerin normalliği analiz edilmiştir. Normal dağılımla ilgili analiz yapmak amacıyla basıklık ve çarpıklık katsayılarına bakılmış ve sonuçlar Tablo 1'de gösterilmiştir.

Tablo 1.

Bağımsız Değişkenlere Göre Ölçek Alt Boyutlarının Basıklık ve Çarpıklık Değerleri

\begin{tabular}{|c|c|c|c|c|c|c|c|c|c|}
\hline $\begin{array}{l}\text { Bağımsız } \\
\text { Değişken }\end{array}$ & Değer & $\begin{array}{c}\text { Kendiliğinden } \\
\text { Başlama }\end{array}$ & Proaktiflik & Israrcılık & $\begin{array}{l}\text { Benlik } \\
\text { Değeri }\end{array}$ & Özgüven & $\begin{array}{c}\text { Depresif } \\
\text { Duygulanım }\end{array}$ & $\begin{array}{l}\text { Kendine } \\
\text { Yetme }\end{array}$ & $\begin{array}{l}\text { Başarma } \\
\text { ve } \\
\text { Üretkenlik }\end{array}$ \\
\hline \multirow{2}{*}{ Yaş } & Basıklık & 0.212 & -0.073 & -0.402 & -0.201 & -0.267 & 0.076 & -0.283 & -0.421 \\
\hline & Çarpıklık & -0.465 & -0.517 & -0.356 & -0.493 & -0.341 & -0.605 & -0.555 & -0.368 \\
\hline \multirow{2}{*}{$\begin{array}{l}\text { Eğitim } \\
\text { Durumu }\end{array}$} & Basıklık & 0.212 & -0.073 & -0.402 & -0.201 & -0.267 & 0.076 & -0.283 & -0.421 \\
\hline & Çarpıklık & -0.465 & -0.517 & -0.356 & -0.493 & -0.341 & -0.605 & -0.555 & -0.368 \\
\hline \multirow{2}{*}{$\begin{array}{c}\text { Mesleki } \\
\text { Hizmet } \\
\text { Süresi }\end{array}$} & Basıklık & 0.212 & -0.073 & -0.402 & -0.201 & -0.267 & 0.076 & -0.283 & -0.421 \\
\hline & Çarpıklık & -0.465 & -0.517 & -0.356 & -0.493 & -0.341 & -0.605 & -0.555 & -0.368 \\
\hline $\begin{array}{l}\text { Görev } \\
\text { Yapılan } \\
\text { Okulun }\end{array}$ & Basıklık & 0.212 & -0.073 & -0.402 & -0.201 & -0.267 & 0.076 & -0.283 & -0.421 \\
\hline $\begin{array}{l}\text { Bulunduğu } \\
\text { Yerleşim } \\
\text { Birimi }\end{array}$ & Çarpıklık & -0.465 & -0.517 & -0.356 & -0.493 & -0.341 & -0.605 & -0.555 & -0.368 \\
\hline
\end{tabular}

George ve Mallery'e (2013) göre çarpıklık ve basıklık değerlerinin ideali -1 ile 1 arasında olmasıdır (0'a yakın olması daha iyi). Bu sebeple ölçek alt boyutlarının çarpıklık ve basıklık değerlerinin -1 ile 1 arasında olması parametrik testler için ön koşullardan birincisi olarak değerlendirilmiştir. Tablo 1'e göre bağımsız değişkenlere göre ölçeklerin alt boyutlarının basıklık ve çarpıklık değerleri -1 ile 1 arasında yer almaktadır. Bunun dışında varyasyon katsayısının 0,5'ten küçük olması ve normal dağılımı gösteren q-q plot grafikleri değerlendirilmiştir. $\mathrm{Bu}$ değerlendirmeler neticesinde verilerin normal dağıldığ 1 varsayılmıştır. Ancak bağımsız değişkenlere göre ölçek alt boyutlarının bazı gruplarında katılımcı sayısının 30'un altında olması durumunda parametrik olmayan testler kullanılmıştır (Büyüköztürk, 2016). Cinsiyet bağımsız değişkeni alt grup sayıları 30'un üzerinde olduğundan parametrik testler; yaş, eğitim durumu, mesleki hizmet süresi ve görev yapılan kurumun bulunduğu yerleşim birimi türü bağımsız değişkenlerinin alt grup sayıları 30'un altında olduğundan parametrik olmayan testler kullanılmıştır.

İstatistik paket programına aktarılan ham veriler öncelikle tanımlayıcı istatistiklerle (yüzde, frekans) betimlenerek yorumlanmıştır. Bu betimlemede Arıcak Benlik Saygısı Ölçeği” ve "Okul Müdürlerinde Kişisel İnisiyatif Ölçme Aracı Okul Müdürü Formu”ndan alınan ortalama puanlar kullanılmıştır. Elde edilen verilerin analizinde aritmetik ortalama ve standart sapma gibi betimsel istatistikler ile t-testi, ANOVA (tek yönlü varyans analizi), Scheffe (Post hoc testi) Kruskal Wallis $\mathrm{H}$ testi, Mann Whitney U testi, Pearson Korelasyonu ve çoklu regresyon analizi kullanılmıştır. Araştırma bulgularının değerlendirilmesinde esas alınan aritmetik ortalama aralıkları; $1.00-1.79=$ "Kesinlikle Katılmıyorum", $1.80-2.59=$ 
"Katılmıorum", 2.60-3.39= "Kararsızım", 3.40-4.19= "Kat1lyorum", 4.20-5.00= "Kesinlikle Katılıyorum" şeklinde yorumlanmıştır.

\section{Bulgular}

$\mathrm{Bu}$ bölümde bulgular, araştırmanın amaçlarına göre sunulmuştur.

\section{Birinci alt probleme ait bulgular}

Okul müdürlerinin benlik saygılarına ve kişisel inisiyatif almalarına ilişkin algıları Tablo 2'de sunulmuştur.

Tablo 2.

Okul Müdürlerinin Benlik Saygılarına ve Kişisel İnisiyatif Alma Durumlarına İlişkin Algıları

\begin{tabular}{llccccccc}
\hline Ölçek & \multicolumn{1}{c}{ Boyutlar } & $\begin{array}{c}\text { Madde } \\
\text { Sayıs }\end{array}$ & $\begin{array}{c}\text { Puan } \\
\text { Aralı̆̆ }\end{array}$ & $\bar{X}$ & $\bar{X} / k$ & ss & Min. & Maks. \\
\hline \multirow{2}{*}{ Benlik Değeri } & 7 & $7-35$ & 29.4 & 4.2 & 0.55 & 2.57 & 5 \\
& Özgüven & 9 & $9-45$ & 38.42 & 4.26 & 0.45 & 3 & 5 \\
$\begin{array}{c}\text { Benlik } \\
\text { Saygis1 }\end{array}$ & Depresif Duygulanım & 5 & $5-25$ & 21.22 & 4.24 & 0.56 & 2.4 & 5 \\
& Kendine Yetme & 5 & $5-25$ & 22.19 & 4.43 & 0.48 & 3 & 5 \\
& Başarma ve Üretkenlik & 6 & $6-30$ & 25.57 & 4.26 & 0.52 & 2.83 & 5 \\
\hline \multirow{2}{*}{$\begin{array}{c}\text { Kişisel } \\
\text { Innisiyatif }\end{array}$} & Kendiliğinden Başlama & 13 & $13-65$ & 53.43 & 4.11 & 0,5 & 2.38 & 5 \\
& Proaktiflik & 9 & $9-45$ & 37.08 & 4.12 & 0.57 & 2.44 & 5 \\
& Israrc1lık & 10 & $10-50$ & 41.9 & 4.19 & 0.51 & 2.8 & 5 \\
\hline
\end{tabular}

Tablo 2'de yer alan ortalama puanların madde sayısına bölünmesi sonucu elde edilen puanlara göre benlik saygısında en yüksek ortalamaya "Kendine yetme" nin $(\bar{X}=4.43)$ sahip olduğu bunu "Özgüven" $(\bar{X}=4.26)$, "Başarma ve Üretkenlik" $(\bar{X}=4.26)$, "Depresif Duygulanım" $(\bar{X}=4.24)$ ve "Benlik Değeri" $(\bar{X}=4.20)$ görüşlerinin takip ettiği söylenebilir. Puan ortalamaları dikkate alındığında okul müdürlerinin "Benlik Değeri”, "Özgüven”, "Depresif Duygulanım”, "Kendine Yetme" ve "Başarma ve Üretkenlik" boyutlarında "tamamen katıllyorum" düzeyinde oldukları söylenebilir. Kişisel İnisiyatif alma durumları incelendiğinde ise "Israrcılık" in $(\bar{X}=4.19)$ en yüksek ortalamaya sahip olduğu bunu "Proaktiflik" $(\bar{X}=4.12)$ ve "Kendiliğinden Başlama" nın $(\bar{X}=4.11)$ izlediği söylenebilir. Okul müdürlerinin kişisel inisiyatif alma durumlarına ait ortalama puanları, onların ilgili boyut ifadelerine büyük ölçüde katıldığını göstermektedir.

\section{İkinci alt probleme ait bulgular}

Okul müdürlerinin eğitim durumu değişkenine göre benlik saygısı ve kişisel inisiyatif alma durumlarının farklılaşma durumu Mann Whitney U testi ile çözümlenerek Tablo 3'te sunulmuştur. 
Tablo 3.

Eğitim Durumu Değişkenine Göre Okul Müdürlerinin Benlik Saygısı ve Kişisel İnisiyatif Alma Durumlarına İlişkin Algıları

\begin{tabular}{|c|c|c|c|c|c|c|c|}
\hline Ölçek & Boyutlar & Eğitim Durumu & $\mathrm{N}$ & $\begin{array}{c}\text { Sira } \\
\text { Ortalamas1 } \\
\end{array}$ & $\begin{array}{c}\text { Sira } \\
\text { Toplamı }\end{array}$ & $\mathrm{U}$ & $\mathrm{p}$ \\
\hline \multirow{10}{*}{$\begin{array}{l}\text { Benlik } \\
\text { Saygis1 }\end{array}$} & \multirow{2}{*}{ Benlik Değeri } & Lisans & 137 & 80.26 & 10995.5 & \multirow{2}{*}{1542.5} & \multirow{2}{*}{0.629} \\
\hline & & Lisansüstü & 24 & 85.23 & 2045.5 & & \\
\hline & \multirow{2}{*}{ Özgüven } & Lisans & 137 & 78.08 & 10696.5 & \multirow{2}{*}{1243.5} & \multirow{2}{*}{0.056} \\
\hline & & Lisansüstü & 24 & 97.69 & 2344.5 & & \\
\hline & \multirow{2}{*}{$\begin{array}{c}\text { Depresif } \\
\text { Duygulanım }\end{array}$} & Lisans & 137 & 79.81 & 10934 & \multirow{2}{*}{1481} & \multirow{2}{*}{0.435} \\
\hline & & Lisansüstü & 24 & 87.79 & 2107 & & \\
\hline & \multirow{2}{*}{$\begin{array}{l}\text { Kendine } \\
\text { Yetme }\end{array}$} & Lisans & 137 & 79.89 & 10944.5 & \multirow{2}{*}{1491.5} & \multirow{2}{*}{0.462} \\
\hline & & Lisansüstü & 24 & 87.35 & 2096.5 & & \\
\hline & \multirow{2}{*}{$\begin{array}{l}\text { Başarma ve } \\
\text { Üretkenlik }\end{array}$} & Lisans & 137 & 78.22 & 10716.5 & \multirow{2}{*}{1263.5} & \multirow{2}{*}{0.069} \\
\hline & & Lisansüstü & 24 & 96.85 & 2324.5 & & \\
\hline \multirow{6}{*}{$\begin{array}{c}\text { Kişisel } \\
\text { İnisiyatif }\end{array}$} & \multirow{2}{*}{$\begin{array}{c}\text { Kendiliğinden } \\
\text { Başlama }\end{array}$} & Lisans & 137 & 79.19 & 10848.5 & \multirow{2}{*}{1395.5} & \multirow{2}{*}{0.238} \\
\hline & & Lisansüstü & 24 & 91.35 & 2192.5 & & \\
\hline & \multirow{2}{*}{ Proaktiflik } & Lisans & 137 & 79.12 & 10839 & \multirow{2}{*}{1386} & \multirow{2}{*}{0.22} \\
\hline & & Lisansüstü & 24 & 91.75 & 2202 & & \\
\hline & \multirow{2}{*}{ Israrcılik } & Lisans & 137 & 77.81 & 10660 & \multirow{2}{*}{1207} & \multirow{2}{*}{ 0.038* } \\
\hline & & Lisansüstü & 24 & 99.21 & 2381 & & \\
\hline
\end{tabular}

Okul müdürlerinin mesleki hizmet süresi değişkenine göre benlik saygısı ve kişisel inisiyatif alma durumlarının farklılaşma durumu Kruskal Wallis H testi ile çözümlenerek Tablo 4' te sunulmuştur.

Tablo 4'e göre okul müdürlerinin benlik değeri $\left(X^{2}{ }_{(3)}=4.973, p>0.05\right)$, özgüven $\left(X^{2}{ }_{(3)}=\right.$ $2.675, \mathrm{p}>0.05)$, depresif duygulanım $\left(\mathrm{X}_{(3)}^{2}=3.245, \mathrm{p}>0.05\right)$ ile başarma ve üretkenlik $\left(\mathrm{X}_{(3)}{ }^{2}=\right.$ $1.100, \mathrm{p}>0.05)$ boyutlarında benlik saygısı düzeylerine ilişkin algıları mesleki hizmet sürelerine göre anlamlı farklılık göstermemektedir. Ancak okul müdürlerinin kendine yetme $\left(\mathrm{X}_{(3)}^{2}=9.228, \mathrm{p}<0.05\right)$ boyutunda benlik saygısı düzeylerine ilișkin algılarının mesleki hizmet sürelerine göre farklılaştığı görülmektedir. Fark yaratan grubun tespit edilmesi için yapılan karşılaştırma testi sonucunda; 31 yıl ve üstü mesleki hizmet süresine sahip okul müdürlerinin 110 y1l, 11-20 yıl ve 21-30 yıl arası mesleki hizmet süresine sahip okul müdürlerinden daha yüksek kendine yetme puanına sahip olduğu bulunmuştur (Mann Whitney U Test; $p<0.05$ ).

Tablo 4'e göre okul müdürlerinin kişisel inisiyatif alma durumlarına ilişkin görüşlerinde kendiliğinden başlama $\left(\mathrm{X}_{(3)}^{2}=1.471, \mathrm{p}>0.05\right)$, proaktiflik $\left(\mathrm{X}_{(3)}^{2}=4.544, \mathrm{p}>0.05\right)$ ve 1 srarcilık $\left(\mathrm{X}_{(3)}^{2}=4.249, \mathrm{p}>0.05\right)$ boyutlarında mesleki hizmet sürelerine göre anlamlı farklılaşma yoktur. 
Tablo 4.

Mesleki Hizmet Süresi Değişkenine Göre Okul Müdürlerinin Benlik Saygısı ve Kişisel İnisiyatif Alma Durumlarına İlişkin Algıları

\begin{tabular}{|c|c|c|c|c|c|c|c|c|}
\hline Ölçek & Boyutlar & $\begin{array}{c}\text { Mesleki } \\
\text { Hizmet Sür. }\end{array}$ & $\mathrm{N}$ & $\begin{array}{c}\text { S1ra } \\
\text { Ortalamas1 }\end{array}$ & sd & $X^{2}$ & $\mathrm{p}$ & $\begin{array}{c}\text { Anlaml } \\
1 \text { Fark }\end{array}$ \\
\hline \multirow{20}{*}{$\begin{array}{l}\text { Benlik } \\
\text { Saygis1 }\end{array}$} & & 1. 1-10 Y1l & 26 & 65.27 & \multirow{4}{*}{3} & \multirow{4}{*}{4.973} & \multirow{4}{*}{0.174} & \multirow{4}{*}{-} \\
\hline & Benlik & 2. 11-20 Y1l & 44 & 79.57 & & & & \\
\hline & \multirow[t]{2}{*}{ Değeri } & 3. 21-30 Y1l & 46 & 81.85 & & & & \\
\hline & & 4. 31 Y1l Üs. & 45 & 90.62 & & & & \\
\hline & \multirow{4}{*}{ Özgüven } & 1. 1-10 Y1l & 26 & 71.44 & \multirow{4}{*}{3} & \multirow{4}{*}{2.675} & \multirow{4}{*}{0.444} & \multirow{4}{*}{-} \\
\hline & & 2. 11-20 Y11 & 44 & 78.74 & & & & \\
\hline & & 3. $21-30 \mathrm{Y}_{11}$ & 46 & 80.37 & & & & \\
\hline & & 4. 31 Y11 Üs. & 45 & 89.38 & & & & \\
\hline & \multirow{4}{*}{$\begin{array}{c}\text { Depresif } \\
\text { Duygulanım }\end{array}$} & 1. 1-10 Y1l & 26 & 76.58 & \multirow{4}{*}{3} & \multirow{4}{*}{3.245} & \multirow{4}{*}{0.355} & \multirow{4}{*}{ - } \\
\hline & & 2. 11-20 Y11 & 44 & 74 & & & & \\
\hline & & 3. 21-30 Y1l & 46 & 80.67 & & & & \\
\hline & & 4. 31 Y11 Üs. & 45 & 90.73 & & & & \\
\hline & \multirow{4}{*}{$\begin{array}{l}\text { Kendine } \\
\text { Yetme }\end{array}$} & 1. 1-10 Y1l & 26 & 65.37 & \multirow{4}{*}{3} & \multirow{4}{*}{9.228} & \multirow{4}{*}{$0.026^{*}$} & \multirow{4}{*}{$\begin{array}{l}1-4 \\
2-4 \\
3-4\end{array}$} \\
\hline & & 2. 11-20 Y11 & 44 & 75.5 & & & & \\
\hline & & 3. 21-30 Y1l & 46 & 79.39 & & & & \\
\hline & & 4. 31 Yil Üs. & 45 & 97.06 & & & & \\
\hline & \multirow{4}{*}{$\begin{array}{l}\text { Başarma ve } \\
\text { Üretkenlik }\end{array}$} & 1. 1-10 Y1l & 26 & 72.65 & \multirow{4}{*}{3} & \multirow{4}{*}{1.100} & \multirow{4}{*}{0.777} & \multirow{4}{*}{ - } \\
\hline & & 2. 11-20 Y11 & 44 & 81.31 & & & & \\
\hline & & 3. 21-30 Y11 & 46 & 84.23 & & & & \\
\hline & & 4. 31 Y1l Üs. & 45 & 82.22 & & & & \\
\hline \multirow{12}{*}{$\begin{array}{c}\text { Kişisel } \\
\text { İnisiyatif }\end{array}$} & \multirow{4}{*}{$\begin{array}{l}\text { Kendiliğind } \\
\text { en Başlama }\end{array}$} & 1. 1-10 Y1l & 26 & 76.56 & & & & \\
\hline & & 2. 11-20 Y11 & 44 & 75.72 & 3 & 1471 & 0689 & \\
\hline & & 3. 21-30 Y11 & 46 & 83.71 & 3 & $1.4 / 1$ & 0.009 & - \\
\hline & & 4. 31 Y11 Üs. & 45 & 85.97 & & & & \\
\hline & & 1. 1-10 Y1l & 26 & 69.73 & & & & \\
\hline & & 2. 11-20 Y1l & 44 & 74.73 & & & & \\
\hline & Proaktı1l1k & 3. 21-30 Y11 & 46 & 83.6 & 3 & 4.544 & 0.208 & - \\
\hline & & 4. 31 Y1l Üs. & 45 & 90.99 & & & & \\
\hline & & 1. 1-10 Yil & 26 & 68.67 & & & & \\
\hline & Israrc1lek & 2. 11-20 Y11 & 44 & 75.44 & 3 & 4249 & 0236 & - \\
\hline & DStartitis & 3. 21-30 Y11 & 46 & 85.2 & 3 & 4.247 & 0.250 & - \\
\hline & & 4. 31 Y1l Üs. & 45 & 89.27 & & & & \\
\hline
\end{tabular}

Okul müdürlerinin yaş değişkenine göre benlik saygısı ve kişisel inisiyatif alma durumlarının farklılaşma durumu Kruskal Wallis $\mathrm{H}$ testi ile çözümlenerek Tablo 5' te sunulmuştur.

Tablo 5'te görüldüğ̈̈ gibi okul müdürlerinin benlik değeri $\left(X^{2}{ }_{(3)}=6.760, p>0.05\right)$, özgüven $\left(\mathrm{X}^{2}{ }_{(3)}=3.756, \mathrm{p}>0.05\right)$, depresif duygulanım $\left(\mathrm{X}_{(3)}{ }^{2}=4.209, \mathrm{p}>0.05\right)$, kendine yetme $\left(\mathrm{X}_{(3)}^{2}=7.61, \mathrm{p}>0.05\right)$ ve başarma ve üretkenlik $\left(\mathrm{X}_{(3)}^{2}=0.704, \mathrm{p}>0.05\right)$ boyutlanında benlik saygısı düzeylerine ilişkin görüşleri yaşlarına göre anlamlı farklılık göstermemektedir.

Tablo 5'e göre okul müdürlerinin kişisel inisiyatif alma durumlarına ilişkin görüşlerinde kendiliğinden başlama ve 1srarcılık boyutlarında yaşa göre anlamlı farklılaşma yoktur. Ancak proaktiflik $\left(\mathrm{X}^{2}{ }_{(3)}=7.97, \mathrm{p}<0.05\right)$ boyutunda okul müdürlerinin görüşleri yaşa göre anlamlı olarak farklılaşmıştır. $\mathrm{Bu}$ farklılığın hangi gruplar arasında olduğunu belirlemek amacıyla yapılan Mann-Whitney U testi analizleri sonucunda; 21-30 arasında yaşı olan okul müdürleri ile 51 ve üzeri yaşı olan $(\mathrm{U}=168.000 ; \mathrm{Z}=-2.205 ; \mathrm{p}<.0 .05), 31-40$ arasında yaşları olan okul 
müdürleri ile 51 ve üzeri yaşı olan $(\mathrm{U}=700.500 ; \mathrm{Z}=-2.126 ; \mathrm{p}<.0 .05), 41-50$ arasında yaşları olan okul müdürleri ile 51 ve üzeri yaşı olan $(U=1264.000 ; Z=-2.008 ; \mathrm{p}<.05)$ okul müdürleri arasında anlamlı bir farklılık görülmüştür. Sıra ortalamaları dikkate alındığında 21-30 yaş grubu okul müdürlerinin proaktiflik boyutuna ilişkin görüşlerinin 51 ve üzeri yaş grubu okul müdürlerine göre daha düşük olduğu, 31-40 yaş grubu okul müdürlerinin proaktiflik boyutuna yönelik görüşlerinin 51 ve üzeri yaş grubu okul müdürlerine göre daha düşük olduğu, 41-50 yaş grubu okul müdürlerinin proaktiflik boyutuna yönelik görüşlerinin 51 ve üzeri yaş grubu okul müdürlerine göre daha düşük olduğu görülmüştür.

Tablo 5.

Yaş Değişkenine Göre Okul Müdürlerinin Benlik Saygısı ve Kişisel İnisiyatif Alma Durumlarına İlişkin Algıları

\begin{tabular}{|c|c|c|c|c|c|c|c|c|}
\hline Ölçek & Boyutlar & Yaş & $\mathrm{N}$ & $\begin{array}{c}\text { S1ra } \\
\text { Ortalamas1 }\end{array}$ & sd & $\mathrm{X}^{2}$ & $\mathrm{p}$ & $\begin{array}{l}\text { Anlaml1 } \\
\text { Fark }\end{array}$ \\
\hline \multirow{20}{*}{$\begin{array}{l}\text { Benlik } \\
\text { Saygis1 }\end{array}$} & \multirow{4}{*}{ Benlik Değeri } & 1. 21-30 Yaş & 11 & 73.23 & \multirow{4}{*}{3} & \multirow{4}{*}{6.76} & \multirow{4}{*}{0.08} & \multirow{4}{*}{-} \\
\hline & & 2. 31-40 Yaş & 36 & 74.5 & & & & \\
\hline & & 3. 41-50 Yaş & 61 & 74.44 & & & & \\
\hline & & 4. 51 Yaş Üs. & 53 & 94.58 & & & & \\
\hline & \multirow{4}{*}{ Özgüven } & 1. 21-30 Yaş & 11 & 69.77 & \multirow{4}{*}{3} & \multirow{4}{*}{3.77} & \multirow{4}{*}{0.288} & \multirow{4}{*}{ - } \\
\hline & & 2. 31-40 Yaş & 36 & 75.17 & & & & \\
\hline & & 3. 41-50 Yaş & 61 & 78.04 & & & & \\
\hline & & 4. 51 Yaş Üs. & 53 & 90.7 & & & & \\
\hline & \multirow{4}{*}{$\begin{array}{c}\text { Depresif } \\
\text { Duygulanım }\end{array}$} & 1. 21-30 Yaş & 11 & 80.5 & \multirow{4}{*}{3} & \multirow{4}{*}{4.21} & \multirow{4}{*}{0.24} & \multirow{4}{*}{ - } \\
\hline & & 2. 31-40 Yaş & 36 & 70.39 & & & & \\
\hline & & 3. 41-50 Yaş & 61 & 79.15 & & & & \\
\hline & & 4. 51 Yaş Üs. & 53 & 90.44 & & & & \\
\hline & \multirow{4}{*}{$\begin{array}{l}\text { Kendine } \\
\text { Yetme }\end{array}$} & 1.21-30 Yaş & 11 & 67.27 & \multirow{4}{*}{3} & \multirow{4}{*}{7.61} & \multirow{4}{*}{0.055} & \multirow{4}{*}{ - } \\
\hline & & 2. 31-40 Yaş & 36 & 70.69 & & & & \\
\hline & & 3. 41-50 Yaş & 61 & 77.91 & & & & \\
\hline & & 4. 51 Yaş Üs. & 53 & 94.41 & & & & \\
\hline & \multirow{4}{*}{$\begin{array}{l}\text { Başarma ve } \\
\text { Üretkenlik }\end{array}$} & 1. 21-30 Yaş & 11 & 73 & \multirow{4}{*}{3} & \multirow{4}{*}{0.70} & \multirow{4}{*}{0.872} & \multirow{4}{*}{ - } \\
\hline & & 2. 31-40 Yaş & 36 & 78.65 & & & & \\
\hline & & 3. 41-50 Yaş & 61 & 80.89 & & & & \\
\hline & & 4. 51 Yaş Üs. & 53 & 84.39 & & & & \\
\hline \multirow{12}{*}{$\begin{array}{l}\text { Kişisel } \\
\text { İnisiyati } \\
\quad \text { f }\end{array}$} & & 1. 21-30 Yaş & 11 & 83.18 & \multirow{4}{*}{3} & & & \\
\hline & Kendiliğinden & 2. 31-40 Yaş & 36 & 73.81 & & & & \\
\hline & Başlama & 3. 41-50 Yaş & 61 & 77.71 & & 2.84 & 0.417 & - \\
\hline & & 4. 51 Yaş Üs. & 53 & 89.22 & & & & \\
\hline & & 1. 21-30 Yaş & 11 & 62.41 & & & & \\
\hline & Proltiflil & 2. 31-40 Yaş & 36 & 72.44 & 2 & 707 & 0.047 & $1-4$ \\
\hline & ProaktıIl1K & 3. 41-50 Yaş & 61 & 77.44 & 3 & 1.91 & 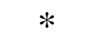 & $\begin{array}{l}2-4 \\
3-4\end{array}$ \\
\hline & & 4. 51 Yaş Üs. & 53 & 94.76 & & & & \\
\hline & & 1. 21-30 Yaş & 11 & 68.5 & & & & \\
\hline & Jsrarc1lik & 2. 31-40 Yaş & 36 & 72.07 & 3 & 486 & 0183 & - \\
\hline & Israrcin1K & 3. 41-50 Yaş & 61 & 79.46 & 3 & 4.80 & 0.183 & - \\
\hline & & 4. 51 Yaş Üs. & 53 & 91.43 & & & & \\
\hline
\end{tabular}

Okul müdürlerinin çalıştıkları kurumların bulunduğu yerleşim biriminin türü değişkenine benlik saygısı ve kişisel inisiyatif alma durumlarının farklılaşma durumu Kruskal Wallis $\mathrm{H}$ testi ile çözümlenerek Tablo 6' da sunulmuştur. 
Tablo 6.

Yerleşim Birimi Türü Değiş̧kenine Göre Okul Müdürlerinin Benlik Saygısı ve Kişisel İnisiyatif Alma Durumlarına İlişkin Algıları

\begin{tabular}{|c|c|c|c|c|c|c|c|c|}
\hline Ölçek & Boyutlar & Yerleşim Türü & $\mathrm{N}$ & $\begin{array}{c}\text { Sira } \\
\text { Ortalamas1 }\end{array}$ & $\mathrm{sd}$ & $X^{2}$ & $\mathrm{p}$ & $\begin{array}{l}\text { Anlaml } \\
\text { Fark }\end{array}$ \\
\hline \multirow{20}{*}{$\begin{array}{l}\text { Benlik } \\
\text { Saygis1 }\end{array}$} & \multirow{4}{*}{ Benlik Değeri } & 1. Köy & 35 & 74.93 & \multirow{4}{*}{3} & \multirow{4}{*}{0.792} & \multirow{4}{*}{0.851} & \multirow{4}{*}{-} \\
\hline & & 2. Belde & 10 & 80.6 & & & & \\
\hline & & 3. İlçe Merkezi & 75 & 83.11 & & & & \\
\hline & & 4. İl Merkezi & 41 & 82.43 & & & & \\
\hline & \multirow{4}{*}{ Özgüven } & 1. Köy & 35 & 66.03 & \multirow{4}{*}{3} & \multirow{4}{*}{5.130} & \multirow{4}{*}{0.163} & \multirow{4}{*}{-} \\
\hline & & 2. Belde & 10 & 94.8 & & & & \\
\hline & & 3. İlçe Merkezi & 75 & 84.78 & & & & \\
\hline & & 4. İl Merkezi & 41 & 83.5 & & & & \\
\hline & \multirow{4}{*}{$\begin{array}{c}\text { Depresif } \\
\text { Duygulanım }\end{array}$} & 1. Köy & 35 & 62.73 & \multirow{4}{*}{3} & \multirow{4}{*}{7.137} & \multirow{4}{*}{0.068} & \multirow{4}{*}{ - } \\
\hline & & 2. Belde & 10 & 83.3 & & & & \\
\hline & & 3. İlçe Merkezi & 75 & 87.37 & & & & \\
\hline & & 4. İl Merkezi & 41 & 84.39 & & & & \\
\hline & \multirow{4}{*}{ Kendine Yetme } & 1. Köy & 35 & 77.4 & \multirow{4}{*}{3} & \multirow{4}{*}{0.551} & \multirow{4}{*}{0.907} & \multirow{4}{*}{-} \\
\hline & & 2. Belde & 10 & 89.2 & & & & \\
\hline & & 3. İlçe Merkezi & 75 & 81.66 & & & & \\
\hline & & 4. İl Merkezi & 41 & 80.87 & & & & \\
\hline & \multirow{4}{*}{$\begin{array}{l}\text { Başarma ve } \\
\text { Üretkenlik }\end{array}$} & 1. Köy & 35 & 61.37 & \multirow{4}{*}{3} & \multirow{4}{*}{8.350} & \multirow{4}{*}{$0.039 *$} & \multirow{4}{*}{$\begin{array}{l}1-3 \\
1-4\end{array}$} \\
\hline & & 2. Belde & 10 & 86.5 & & & & \\
\hline & & 3. İlçe Merkezi & 75 & 88.25 & & & & \\
\hline & & 4. İl Merkezi & 41 & 83.15 & & & & \\
\hline \multirow{12}{*}{$\begin{array}{c}\text { Kişisel } \\
\text { İnisiyatif }\end{array}$} & \multirow{4}{*}{$\begin{array}{l}\text { Kendiliğinden } \\
\text { Başlama }\end{array}$} & 1. Köy & 35 & 67.14 & & & & \\
\hline & & 2. Belde & 10 & 74.4 & & & & \\
\hline & & 3. İlçe Merkezi & 75 & 81.49 & 3 & 6.284 & 0.099 & - \\
\hline & & 4. İl Merkezi & 41 & 93.54 & & & & \\
\hline & & 1. Köy & 35 & 52.93 & & & & \\
\hline & & 2. Belde & 10 & 95.3 & & & & $1-2$ \\
\hline & Proaktiflik & 3. İlçe Merkezi & 75 & 84.53 & 3 & 17.842 & $0.000^{*}$ & $\begin{array}{l}1-3 \\
1-4\end{array}$ \\
\hline & & 4. İl Merkezi & 41 & 95.01 & & & & \\
\hline & & 1. Köy & 35 & 60.74 & & & & \\
\hline & & 2. Belde & 10 & 85.55 & & & & $1-3$ \\
\hline & Israrc1l1K & 3. İlçe Merkezi & 75 & 85.56 & 3 & 8.619 & $0.035^{*}$ & $1-4$ \\
\hline & & 4. İl Merkezi & 41 & 88.84 & & & & \\
\hline
\end{tabular}

Tablo 6'da görüldüğü üzere okul müdürlerinin benlik değeri $\left(\mathrm{X}_{(3)}^{2}=0.851, \mathrm{p}>0.05\right)$, özgüven $\left(\mathrm{X}_{(3)}=0.163 \mathrm{p}>0.05\right)$, depresif duygulanım $\left(\mathrm{X}_{(3)}=0.068, \mathrm{p}>0.05\right)$, kendine yetme $\left(\mathrm{X}^{2}{ }_{(3)}=0.907, \mathrm{p}>0.05\right)$ boyutlarında benlik saygısı düzeylerine ilişkin algıları çalıştıkları kurumun bulunduğu yerleşim birimi türüne göre anlamlı farklılık göstermemektedir. Başarma ve üretkenlik $\left(\mathrm{X}_{(3)}^{2}=8.350, \mathrm{p}<0.05\right)$ boyutunda ise okul müdürlerinin benlik saygısı düzeylerine ilişkin görüşleri çalıştıkları kurumun bulunduğu yerleşim birimi türüne göre anlamlı farklılık göstermektedir. Fark yaratan grubun tespit edilmesi için yapılan karşıllaştırmalar sonucunda; köyde görev yapan okul müdürlerinin ilçe merkezi ve il merkezinde görev yapan okul 
müdürlerinden daha düşük başarma ve üretkenlik puanına sahip olduğu bulunmuştur (Mann Whitney U Test; $\mathrm{p}<0.05)$.

Tablo 6'ya göre okul müdürlerinin kişisel inisiyatif alma durumlarına ilişkin görüşlerinde kendiliğinden başlama $\left(\mathrm{X}^{2}{ }_{(3)}=6.284, \mathrm{p}>0.099\right)$ boyutunda kurumun bulunduğu yerleşim birimi türüne göre anlamlı farklılaşma yoktur. Ancak proaktiflik $\left(\mathrm{X}^{2}{ }_{(3)}=17.840, \mathrm{p}<\right.$ $0.05)$ ve 1srarcılık $\left(\mathrm{X}^{2}{ }_{(3)}=8.619, \mathrm{p}<0.05\right)$ boyutlarında okul müdürlerinin görüşleri kurumlarındaki yerleşim birimi türüne göre anlamlı olarak farklılaşmıştır. Bu farklılığın hangi gruplar arasında olduğunu belirlemek amacıyla değişik sayıda ikili Mann-Whitney U testi karşılaştırmaları yapılmıştır. Mann-Whitney $U$ testi analizleri sonucunda şu bulgulara ulaşılmıştır: Okul müdürlerinin kişisel inisiyatif alma durumlarına ilişkin görüşleri, proaktiflik boyutunda; yerleşim birimi köy olanlar ile yerleşim birimi türü belde $(U=92.000 ; Z=-2.274$; $\mathrm{p}<0.05)$ olanlar, yerleşim birimi türü köy olanlar ile yerleşim birimi türü ilçe merkezi $(\mathrm{U}=794.500 ; \mathrm{Z}=-3.333 ; \mathrm{p}<0.05)$ olanlar ve kurumlarının bulunduğu yerleşim birimi türü köy olanlar ile kurumlarının bulunduğu yerleșim birimi türü il merkezi $(U=336.000 ; Z=-3.985$; $\mathrm{p}<0.05$ ) olanlar arasında anlamlı farklılık olduğu görülmüştür. Yine okul müdürlerinin kişisel inisiyatif alma durumlarına ilişkin görüşleri, ısrarcılık boyutunda; yerleşim birimi köy olanlar ile kurumlarının bulunduğu yerleşim birimi türü ilçe merkezi $(U=916.000 ; Z=-2.551 ; p<0.05)$ olanlar ve kurumlarının bulunduğu yerleşim birimi türü köy olanlar ile kurumlarının bulunduğu yerleşim birimi türü il merkezi $(\mathrm{U}=464.000 ; \mathrm{Z}=-2.649 ; \mathrm{p}<0.05)$ olanlar arasında anlamlı farklıl1k olduğu görülmüsstür.

Sıra ortalamalarına yerleşim birimi köy olan okul müdürleri proaktiflik boyutunda okul müdürlerinin kişisel inisiyatif alma durumlarına ilişkin görüşleri yerleşim birimi belde, ilçe merkezi ve il merkezi olan okul müdürlerine göre daha düşük bulunmuştur. Israrcılık boyutunda da yerleşim birimi köy olan okul müdürlerinin kişisel inisiyatif alma durumlarına ilişkin görüşleri yerleşim birimi türü ilçe merkezi ve il merkezi olan okul müdürlerine göre daha düşük bulunmuştur.

\section{Üçüncü alt probleme ait bulgular}

Okul müdürlerinin benlik saygıları ile kişisel inisiyatif alma durumları arasında anlamlı bir ilişki olup olmadığını belirlemek için Pearson korelasyon katsayısı hesaplanmış ve Tablo 7'de sunulmuştur.

Tablo 7.

Okul Müdürlerinin Benlik Saygısı Düzeyleri ile Kişisel İnisiyatif Alma Durumları Arasındaki İlişki

\begin{tabular}{cccc}
\hline & & Kişisel İnisiyatif & Benlik Saygıs1 \\
\hline \multirow{3}{*}{ Kişisel İnisiyatif } & $\mathrm{r}$ & 1 &, $683^{* *}$ \\
& $\mathrm{p}$ & & 0,000 \\
& $\mathrm{n}$ & 161 & 161 \\
\hline \multirow{3}{*}{ Benlik Saygisı } & $\mathrm{r}$ &, $683^{* *}$ & 1 \\
& $\mathrm{p}$ & 0,000 & 161 \\
\hline
\end{tabular}

**Korelasyon.01 düzeyinde anlamlıdır.

Tablo 7'de görüldügü gibi gerçekleştirilen korelasyon analizinden elde edilen bulgulara göre okul müdürü benlik saygısı düzeyleri ile kişisel inisiyatif alma durumları arasında $(\mathrm{r}=.683)$ orta düzeyde pozitif düzeyde bir ilişki vardır. Okul müdürlerinin benlik saygısı düzeyleri arttıkça kişisel inisiyatif alma durumlarının da arttığı söylenebilir.

\section{Dördüncü alt probleme ait bulgular}

Öğretmen adaylarının tartışma becerilerinin iletişim becerilerinin yordayıcısı olmasına dair elde edilen bulgu Tablo 8'de sunulmuştur. 
Tablo 8.

Okul Müdürlerinin Benlik Saygısı Düzeylerinin Kişisel İnisiyatif Alma Durumlarını Yordama Düzeyi

\begin{tabular}{|c|c|c|c|c|c|c|c|}
\hline Değişken & B & Standart Hata & $\beta$ & $\mathrm{T}$ & $\mathrm{p}$ & $\begin{array}{c}\text { İkili } \\
\mathrm{r}\end{array}$ & $\begin{array}{c}\text { K1smi } \\
\mathrm{r}\end{array}$ \\
\hline Kendiliğinden Başlama (Sabit) & 1,072 & 0,313 & - & 3,422 & 0,001 & - & - \\
\hline Benlik Değeri & 0,194 & 0,081 & 0,211 & 2,394 & 0,018 & 0,565 & 0,189 \\
\hline Özgüven & 0,307 & 0,118 & 0,275 & 2,614 & 0,010 & 0,611 & 0,205 \\
\hline Depresif Duygulanım & $-0,063$ & 0,071 & $-0,070$ & $-0,881$ & 0,380 & 0,399 & $-0,071$ \\
\hline Kendine Yetme & $-0,068$ & 0,081 & $-0,066$ & $-0,840$ & 0,402 & 0,392 & $-0,067$ \\
\hline Başarma ve Üretkenlik & 0,347 & 0,093 & 0,362 & 3,748 & 0,000 & 0,626 & 0,288 \\
\hline $\mathrm{R}=0,678 \quad \mathrm{R}_{2}=0,459$ & $\mathrm{dj} \mathrm{R}_{2}=0$ & 442 & & & & & \\
\hline $\mathrm{F}_{(5,155)}=26,340 \quad \mathrm{p}=0,000$ & & & & & & & \\
\hline Proaktiflik (Sabit) & 0,416 & 0,344 & - & 1,209 & 0,229 & - & - \\
\hline Benlik Değeri & 0,241 & 0,089 & 0,231 & 2,703 & 0,008 & 0,597 & 0,212 \\
\hline Özgüven & 0,435 & 0,129 & 0,343 & 3,373 & 0,001 & 0,657 & 0,262 \\
\hline Depresif Duygulanım & 0,040 & 0,078 & 0,039 & 0,506 & 0,614 & 0,477 & 0,041 \\
\hline Kendine Yetme & $-0,086$ & 0,089 & $-0,073$ & $-0,961$ & 0,338 & 0,414 & $-0,077$ \\
\hline Başarma ve Üretkenlik & 0,247 & 0,102 & 0,227 & 2,429 & 0,016 & 0,618 & 0,191 \\
\hline \multicolumn{8}{|c|}{$\begin{array}{lll}R=0,702 & R_{2}=0,492 & \text { Adj } R_{2}=0,476\end{array}$} \\
\hline \multicolumn{8}{|l|}{$F_{(5,155)}=30,060 \quad p=0,000$} \\
\hline Israrcılık (Sabit) & 1,105 & 0,322 & - & 3,435 & 0,001 & - & - \\
\hline Benlik Değeri & 0,198 & 0,083 & 0,212 & 2,379 & 0,019 & 0,562 & 0,188 \\
\hline Özgüven & 0,376 & 0,121 & 0,332 & 3,119 & 0,002 & 0,621 & 0,243 \\
\hline Depresif Duygulanım & $-0,017$ & 0,073 & $-0,019$ & $-0,229$ & 0,819 & 0,423 & $-0,018$ \\
\hline Kendine Yetme & $-0,086$ & 0,083 & $-0,082$ & $-1,033$ & 0,303 & 0,382 & $-0,083$ \\
\hline Başarma ve Üretkenlik & 0,260 & 0,095 & 0,267 & 2,737 & 0,007 & 0,597 & 0,215 \\
\hline \multicolumn{8}{|c|}{$\mathrm{R}=0,668 \quad \mathrm{R}_{2}=0,446 \quad$ Adj $\mathrm{R}_{2}=0,428$} \\
\hline$F_{(5,155)}=24,934 \quad p=0,000$ & & & & & & & \\
\hline
\end{tabular}

Okul müdürlerinin kişisel inisiyatif alma durumlarının benlik saygısı düzeyleri tarafından yordanma düzeyini belirlemek için çoklu regresyon analizi yapılmıştır. Buna göre Tablo 8'de görüldügü gibi benlik saygısı alt boyutlarının kendiliğinden başlamayı yordama durumunu test eden model anlamlıdır $\left(\mathrm{F}_{(5-155)}=26.340\right.$, $\left.\mathrm{p}<0.05\right)$. Benlik değeri, özgüven, depresif duygulanım, kendine yetme, başarma ve üretkenlik boyutları birlikte kendiliğinden başlamanın \% 44'ünü yordamaktadır (Adj. $\mathrm{R}_{2}=0.442$ ). Benlik saygısı alt boyutlarının 1srarcılığ yordama durumunu test eden model anlamlidır $\left(\mathrm{F}_{(5-155)}=30.060, \mathrm{p}<0.05\right)$. Benlik değeri, özgüven, depresif duygulanım, kendine yetme, başarma ve üretkenlik boyutları birlikte proaktifliğin \% 47'sini yordamaktadır (Adj. $\mathrm{R}_{2}=0.476$ ). Benlik saygısı alt boyutlarının proaktifliği yordama durumunu test eden model anlamlıdır $\left(\mathrm{F}_{(5-155)}=24.934, \mathrm{p}<0.05\right)$. Benlik değeri, özgüven, depresif duygulanım, kendine yetme, başarma ve üretkenlik boyutları birlikte 1srarcılığın \% 42'sini yordamaktadır (Adj. $\mathrm{R}_{2}=0.428$ ).

\section{Tartışma ve Sonuç}

Araştırma bulgularına göre; alınan puan ortalamaları dikkate alındığında okul müdürleri benlik saygısı düzeylerine ilişkin algılarında en yüksekten en düşüğe sırasıyla kendine yetme, özgüven, başarma ve üretkenlik, depresif duygulanım ve benlik değeri boyutlarında "tamamen kat1lyyorum" düzeyinde yüksek şekilde yeterli görmektedir. Bu durumda okul müdürlerinin girişken, sosyal, dişa dönük, kendilerine inanan ve güvenen bireyler oldukları söylenebilir. Bu 
açıdan okul müdürlerinin kişisel inisiyatif almaya hazır oldukları söylenebilir. Madenoğlu'nun (2010) çalışmasında da eğitim örgütü yöneticilerinin orta ve yüksek benlik saygısı düzeylerine sahip olduğu bulunmuştur.

Okul müdürlerinin kendine yetme boyutunda benlik saygısı düzeylerine ilişkin algılarının mesleki hizmet sürelerine göre farklılaştığı görülmüştür. Fark yaratan grubun tespit edilmesi için yapılan çoklu karşılaştırmalar sonucunda; 31 yıl ve üstü mesleki hizmet süresine sahip okul müdürlerinin 1-10 yıl, 11-20 yıl ve 21-30 yıl arası mesleki hizmet süresine sahip okul müdürlerinden daha yüksek kendine yetme puanına sahip olduğu bulunmuştur. $\mathrm{Bu}$ bulgu mesleki hizmet süresi 31 ve üstü yıl olan okul müdürlerinin 1-10 yıl, 11-20 yıl ve 21-30 yıl aras1 mesleki hizmet süresine sahip okul müdürlerine göre bireyin zihinsel ve davranışsal anlamda kendi beklentilerini, hedeflerini gerçekleştirme durumu anlamına gelen kendine yetme boyutunda kendileriyle daha barışık oldukları şeklinde yorumlanabilir. Yine bu farklılığın sebebi mesleki hizmet süresi 31 ve üstü yıl olan okul müdürlerinin yıllar içinde edindikleri deneyim, karşılaştıkları sorunların çeşitliliği ve mesleklerinin inceliklerini daha iyi kavramalarından kaynaklanan daha gerçekçi beklenti ve hedefler oluşturabilme becerilerinin gelişmesi veya oluşturdukları beklenti ve hedeflerini yıllar içinde gerçekleştirmeleri, tamamlamaları olabilir.

Başarma ve üretkenlik boyutunda okul müdürlerinin benlik saygısı düzeylerine ilişkin görüşleri çalıştıkları kurumun bulunduğu yerleşim birimi türüne göre anlamlı farklılık göstermektedir. Fark yaratan grubun tespit edilmesi için yapılan karşıllaştırmalar sonucunda; köyde görev yapan okul müdürlerinin ilçe merkezi ve il merkezinde görev yapan okul müdürlerinden daha düşük başarma ve üretkenlik puanına sahip olduğu bulunmuştur. Bu bulgu görev yaptıkları kurumun bulunduğu yerleşim biriminin türü köy olan okul müdürlerinin benlik saygısı düzeylerinin bireyin kendini yeterince başarılı ve faydalı görme durumu anlamına gelen başarma ve üretkenlik boyutunda görev yaptıkları kurumun bulunduğu yerleşim biriminin türü ilçe merkezi ve il merkezi olan okul müdürlerine göre daha az başarılı ve faydalı görüyor oldukları șeklinde yorumlanabilir. Görev yaptıkları kurumlarının bulunduğu yerleșim biriminin türü köy olan okul müdürlerinin kendilerini kurumlarının bulunduğu yerleşim birimi türü ilçe merkezi ve il merkezi olan okul müdürlerine göre daha az başarılı ve faydalı görmelerinde görev yaptıkları yerleşim birimi olan köylerin ilçe merkezi ve il merkezlerine göre daha yalıtılmış yerler olmasından kaynaklanıyor olabilir. Köylerde görev yapan okul müdürlerinin okulları ile ilgili yapmak isteyip de köyde olmanın getirdiği birtakım olumsuz şartlar dolayısıyla bu isteklerini ertelemeleri veya bu isteklerinden vazgeçmeleri onların il ve ilçe merkezlerindeki okullarda görev yapan okul müdürlerine göre kendilerini daha az başarılı görmelerine sebep oluyor olabilir.

Alınan puan ortalamaları dikkate alındığında okul müdürlerinin kişisel inisiyatif alma durumlarına ilişkin görüşlerinde en yüksekten en düşüğe sırasıyla 1srarcılık, proaktiflik ve kendiliğinden başlama boyutlarında "büyük ölçüde katılıyorum" düzeyinde yüksek şekilde yeterli görmektedir. Okul müdürlerinin kişisel inisiyatif alma davranışları sergilemekten çekinmedikleri söylenebilir. Akın'ın (2012) çalışmasında da okul müdürlerinin kişisel inisiyatif alma durumlarına ilişkin görüşlerinin kendiliğinden başlama, proaktiflik ve 1srarcılık boyutlarında "tamamen katılıyorum" düzeyinde yüksek şekilde olduğu görülmüştür.

Okul müdürlerinin kişisel inisiyatif alma durumları 1srarcılık boyutunda eğitim durumlarına göre anlamlı şekilde farklılaşmaktadır. Lisansüstü mezuniyete sahip olan okul müdürlerinin lisans mezunu olan okul müdürlerine göre daha yüksek 1srarcılık puanına sahip olduğu söylenebilir. Bu bulguya göre lisansüstü mezuniyete sahip olan okul müdürlerinin kendi görüşlerine göre uzun vadeli hedeflerin uygulanmasında karşılaşılan zorlukların üstesinden gelmede firsat arayışından vazgeçmeme anlamına gelen kişisel inisiyatif almada 1srarcı olma konusunda kendilerini lisans mezunu okul müdürlerine göre daha yeterli gördükleri söylenebilir. Lisansüstü mezuniyete sahip okul müdürleri mesleki becerilerini arttırmak amacıyla aldıkları lisansüstü eğitimin, onların hedeflerine ulaşırken karşılaştıkları zorluklara yönelik çözüm üretmekten ve firsat aramaktan vazgeçmemede kolaylık sağladığını düşünüyor olabilirler. $\mathrm{Bu}$ bakımdan lisansüstü eğitim ile edinilen uzmanlık bilgisi ve bilimsel, metodolojik bakış açısının 
okul müdürlerinin hedeflerine ulaşırken zorluklar karşısında firsat arayışında ısrarcı olmalarını ve kişisel inisiyatif almalarını sağladıkları söylenebilir. Akın'ın (2012) okul müdürlerinin kişisel inisiyatif alma durumlarına ilişkin çalışmasında ise okul müdürlerinin ve müdür yardımcılarının görüşleri kendiliğinden başlama, proaktiflik ve 1srarcılık boyutlarında eğitim düzeylerine göre anlamlı biçimde farklılaşmadığı sonucunu bulunmuştur.

Okul müdürlerinin kişisel inisiyatif alma durumları proaktiflik boyutunda yaşlarına göre anlamlı şekilde farklılaşmaktadır. 51 ve üstü yaşa sahip olan okul müdürleri 21-30, 31-40 ve 4150 yaş aralıklarında olan okul müdürlerine göre daha yüksek proaktiflik puanına sahip oldukları görülmüştür. $\mathrm{Bu}$ bulguya göre 51 ve üzeri yaş grubu okul müdürleri kendi görüşlerine göre gelecekte ortaya çıkabilecek talep, tekrarlanan sorun ve firsatları dikkate alarak bunlar hakkında tanımlanmış rollerinin dışına çıkıp hazırlıklı olma anlamına gelen kişisel inisiyatif almada proaktif olma konusunda 21-30, 31-40 ve 41-50 aras1 yaş gruplarına göre kendilerini daha yeterli görmektedir. 51 ve üzeri yaşta olan okul müdürleri yaş itibariyle gerek hayat ile ilgili gerekse mesleki deneyime sahip olduklarından ortaya çıkabilecek talep, sorun ve firsatlara daha önceki deneyimlerinden hareketle daha hazır olabileceklerini düşünüyor olabilirler.

Okul müdürlerinin kişisel inisiyatife ilişkin görüşleri proaktiflik ve 1srarcıllk boyutlarında görev yaptıkları kurumun bulunduğu yerleşim birimi türüne göre anlamlı şekilde farklılaşmıştır. Köyde görev yapan okul müdürlerinin kişisel inisiyatif almanın proaktiflik boyutunda; belde, ilçe merkezi ve il merkezinde görev yapan okul müdürlerine göre, 1srarcılık boyutunda ise ilçe ve il merkezinde görev yapan okul müdürlerine göre daha düşük puana sahip oldukları görülmüştür. Bu bulguya göre 51 ve üzeri yaş grubu okul müdürleri kendi görüşlerine göre gelecekte ortaya çıkabilecek talep, tekrarlanan sorun ve firsatları dikkate alarak bunlar hakkında tanımlanmış rollerinin dışına çıkıp hazırlıklı olma anlamına gelen kişisel inisiyatif almada proaktif olma konusunda $21-30,31-40$ ve 41-50 aras1 yaş gruplarına göre kendilerini daha yeterli görmektedir. 51 ve üzeri yaşta olan okul müdürleri yaş itibariyle gerek hayat ile ilgili gerekse mesleki deneyime sahip olduklarından ortaya çıkabilecek talep, sorun ve fırsatlara daha önceki deneyimlerinden hareketle daha hazır olabileceklerini düşünüyor olabilirler. Koçak ve Eves'in (2010) okul yöneticileri ile gerçekleştirdikleri çalışmada, okul yöneticilerinin problem çözme becerisi toplam puanlarında okulun bulunduğu yerleşim yerine göre anlamlı farklılık oluştuğu bulgusuna ulaşılmıştır. Buna göre kasaba, köy ya da beldede çalışan okul yöneticilerinin problem çözme becerilerinin il ve ilçe merkezinde çalışan okul yöneticilerinin problem çözme becerilerinden düşük olduğu görülmüştür.

Araştırmada okul müdürlerinin benlik saygısı düzeyleri ile kişisel inisiyatif alma durumları arasında orta düzeyde pozitif bir ilişki olduğu bulunmuştur. Okul müdürlerinin benlik saygıları arttıkça kişisel inisiyatif alma durumları da artış göstermektedir. Yani okul müdürlerinin kişisel inisiyatif davranışı göstermesinde kendilerine ilişkin olumlu algıları önemli bir yer teşkil etmektedir. Okul müdürlerinin kişisel inisiyatif almalarını teşvik etmede benlik saygılarının önemli bir yeri olduğu söylenebilir.

Proaktiflik ve ısrarcılığın en önemli yordayıcısı özgüven iken, kendiliğinden başlamanın en önemli yordayıcısı başarma ve üretkenliktir. Buna göre açıkça belirtilmeksizin iş tanımının ötesinde bir hedefin geliştirilip izlenmesi anlamına gelen kendiliğinden başlama davranışının okul müdürlerinin kendini yeterince başarılı ve faydalı görme durumu anlamına gelen başarma ve üretkenlikten kaynaklandığı görülmektedir. Ayrıca uzun vadeli hedefleri uygularken karşılaşılabilecek sorun ve firsatlara hazırlıklı olma anlamına gelen proaktiflik davranışı ile karşılaşılan sorun ve firsatların üstesinden gelmede firsat arayışından vazgeçmeme anlamına gelen ısrarcılık davranışının daha çok kendi özelliklerine bir değer atfetme ve bu değerler sayesinde kendini onaylama durumu anlamına gelen özgüvenden beslendiği görülmüştür. $\mathrm{Bu}$ farklılığın sebebi ise kendiliğinden başlama davranışının başarma ve üretkenlik algıları ile; proaktiflik ve ısrarcılık davranışlarının ise özgüven algıları ile ilgili olmasından kaynaklanıyor olabilir. 


\section{Öneriler}

1- Araştırmanın sonuçları okul müdürlerinin kişisel inisiyatif almada üst makamların etkisinde olarak daha çok üst makamların talimatlarına göre hareket ettiklerini göstermektedir. Bu bakımdan okul müdürlerinin kişisel inisiyatif almada üst makamlarca desteklenmeleri onların daha fazla kişisel inisiyatif almalarını sağlayabilir. Üst makamlarca okul müdürlerinin kişisel inisiyatif alabilecekleri alanların genişletilmesi sağlanabilir.

2- Araştırma sonuçlarına göre lisansüstü mezuniyete sahip okul müdürlerinin lisans mezunu okul müdürlerine göre kişisel inisiyatif almada daha fazla ısrarcı davranışlar sergilediği belirlenmiştir. Bu bakımdan okul müdürlerinin özellikle eğitim yönetimi alanında lisansüstü eğitiminin okul yöneticilerinin daha fazla kişisel inisiyatif almalarını sağlayacaktır. Bu bakımdan okul müdürlerinin lisansüstü eğitimi MEB tarafından teşvik edilmelidir.

3- Araştırma sonuçlarına göre okul müdürlerinin kişisel inisiyatif almada proaktif davranışları yaş ilerledikçe artış göstermektedir. Yine okul müdürlerinin mesleki hizmet süreleri arttıkça benlik saygıları kendine yetme boyutunda artmaktadır. Bu bakımdan genç yaştaki veya mesleğin başındaki okul müdürlerinin okul yönetiminde öngörülü olabilmeleri, yenilik yaratabilmeleri ve deneyimlerini arttırabilmeleri için deneyimli okul müdürlerinden yararlanabilecekleri ortamların, platformların, e-forumların oluşturulması sağlanabilir.

4- Araştırma sonuçlarına göre görev yapılan kurumun bulunduğu yerleşim birimi büyüdükçe okul müdürlerinin kişisel inisiyatif alma durumları özellikle proaktiflik ve ısrarcılık davranışları açısından artış göstermektedir. Yine benlik saygısı bakımından görev yaptıkları kurumun bulunduğu yerleşim birimi köy olan okul müdürlerinin, görev yaptıkları kurumun bulunduğu yerleşim birimi ilçe ve il merkezi olan okul müdürlerine göre daha düşük başarma ve üretkenlik puanına sahip olduğu görülmüştür. Bu sebeple küçük yerleşim birimlerinde görev yapan okul müdürlerinin görev yaptıkları yerleşim biriminin eğitim öğretim olanaklarının geliştirilmesi yahut olanaklara ulaşım yollarının desteklenmesi sağlanabilir.

5- Araştırma sonuçları okul müdürlerinin benlik saygılarının arttıkça kişisel inisiyatif alma davranışlarının da arttığını göstermektedir. Bu sebeple okul müdürlerinin benlik saygılarının yükselmesi için konunun uzmanlarınca kişisel gelişimlerini sağlayacak seminerler düzenlenmesi sağlanabilir. Yine okul müdürlerinin seçiminde benlik saygısı düzeylerinin de dikkate alınacağı bir model geliştirilebilir.

\section{Kaynaklar}

Akın, U. (2012). Kamu ilköğretim okulu müdürlerinin kişisel inisiyatif alma durumlari ve öz yeterlikleriyle ilişkisi (Yayımlanmamış doktora tezi). Ankara Üniversitesi, Eğitim Bilimleri Enstitüsü, Ankara.

Arıcak, O. T. (1999). Grupla psikolojik danışma yoluyla benlik saygısı ve mesleki benlik saygısının geliştirilmesi (Yayımlanmamış doktora tezi). Marmara Üniversitesi, Sosyal Bilimler Enstitüsü, İstanbul.

Balc1, A. (2013). Sosyal bilimlerde araştırma: yöntem, teknik ve ilkeler (10. Bask1). Ankara: PegemA.

Balc1, A. (2000). İkibinli Yıllarda Türk milli eğitim sisteminin örgütlenmesi ve yönetimi. Kuram ve Uygulamada Ĕ̈itim Yönetimi, 24, 495-508.

Balyer, A. (2012). Çağdaş okul müdürlerinin değişen rolleri. Ahi Evran Üniversitesi Kırşehir Eğitim Fakültesi Dergisi (KEFAD), 13(2), 75-93.

Baumeister, R. F., Campbell, J. D., Krugger, J. I. ve Vohs, K. D. (2003). Does high self-esteem cause better performance, interpersonal success, happiness or healthier lifesyles? Psychological Science in the Public Interest, 4(1), 1-44.

Binbaşıoğlu, C. (1988). Eğitim yöneticiliği. Ankara: Binbaşığlu Yayınevi. 
Bursalığlu, Z. (1991). Okul yönetiminde yeni yapı ve davranış (8. Bask1). Ankara: PEGEM Yayınlar1.

Büyüköztürk, Ş. (2016). Sosyal bilimler için veri analizi el kitabi (22. Bask1). Ankara: Pegem Akademi

Coopersmith, S. (1967). The Antecedents of self- esteem. San Francisco: W.H. Freeman \& Co.

Çelik, V. (2004). Eğitimsel reform için yeni bir okul kültürü. eğitimize bakışlar. İ. Fındıkçı (Yay. haz.). İstanbul: Kültür Koleji Eğitim Vakfi Yayınları.

Dönmez, B. ve Güven, M. (2001). Friedman okul müdürleri tükenmişlik ölçeğinin türkiye’ye uyarlama çalışması. Kuram ve Uygulamada Eğitim Yönetimi Dergisi, 7(26), 221-225.

Fay, D. ve Frese, M. (2000). Self-Starting behavior at work: toward a theory of personal initiative. motivational psychology of human development. J.H. (Yay. haz.). Amsterdam: Elsevier Science.

Frese, M. (2009). Toward a psychology of entrepreneurship-an action theory perspective. Foundations And Trends In Entrepreneurship, 5(6), 435-494.

Frese, M. ve Fay, D. (2001). Personal initiative (PI): An active performance concept for work in the 21. Century. Research in Organizational Behavior (23), 133-187.

Frese, M., Garst, H. ve Fay, D. (2007). Making Things happen: reciprocal relationships between work characteristics and personal initiative (PI) in a Four-wave longitudinal structural equation model. Journal of Applied Psychology, 92(4), 1084-1102.

Frese, M., Kring, W., Soose, A. ve Zempel, J. (1996). Personal initiative at work: Defferences between East and West Germany. Academy of Management Journal, 39(1), 37.

George, D. ve Mallery, P. (2013). SPSS for windows step by step: a simple guide for reference 11.0 update. (4th Edition). Boston: Allyn \& Bacon.

Grant, A. M. ve Ashford, S. J. (2008). The dynamics of proactivity at work. Research In Organizational Behavior, 28, 3-34.

Güngör, A. (1989). Lise öğrencilerinin özsaygı düzeylerini etkileyen etmenler. (Yayınlanmamış doktora tezi). Hacettepe Üniversitesi, Sosyal Bilimler Enstitüsü, Ankara.

Karasar, N. (2008). Bilimsel araştırma yöntemi: kavramlar- ilkeler- teknikler. Ankara: Nobel Yayıncilik.

Koçak, R. ve Eves, S. (2010). Okul Yöneticilerinin iş doyumları ile problem çözme becerileri arasındaki ilişki. Uluslararası İnsan Bilimleri Dergisi, 7(1), 193-212.

Kuzgun, Y. (2002). İlköğretimde rehberlik. Ankara: Nobel Yayın Dağıtım.

Madenoğlu, C. (2010). Eğitim örgütü yönetcilerinin örgütsel stres kaynakları ve stresle başa çıkma tarzlarının benlik saygısı düzeyleriyle olan ilişkisi. (Yayımlanmamış doktora tezi). Anadolu Üniversitesi, Sosyal Bilimler Enstitüsü, Eskişehir.

Mann, M. M., Hosman, C., Schaalma, H. ve Vries, N. D. (2004). Self-Esteem in A broadspectrum approach for mental health promotion. Health Education Research, 19(4), 357-372.

Şişman, M. ve Turan, S. (2004). Ĕgitim ve okul yönetimi. eğitim ve okul yöneticiliği. Y.Özden (Yay. haz.). Ankara: PegemA Yayincilık.

Yavuzer, H. (2003). Okul çağı çocuğu (9.Bask1). İstanbul: Remzi Kitabevi.

Yörükoğlu, A. (2000). Gençlik çă̆ı ruh sağlı̆̆ı eğitimi ve ruhsal sorunları (11.Baskı). İstanbul: Özgür Yayınları.

\section{Extended Abstract}

\section{Introduction}

Personal initiative is an active performance concept that expresses the employee's interpretation of the role, the creation of new objectives for the benefit of the organization and the persistent implementation of these objectives (Akın, 2012). The self-determination of the employee to create innovation, the desire to do more than expected in his / her job, the desire to tackle the difficulties faced, the determination to overcome the obstacles, the level of being proactive, his / 
her qualifications and character traits determine the level of initiative of individuals (Fay and Frese, 2001). The initiative has become increasingly important in today's organizations, and they want employees who are innovative and can take action without waiting for someone to tell them what to do. As a result, such flexibility and elasticity enable organizations to increase their innovation and overcome difficulties (Frese, 2009). In the traditional system, the principal task of the school principal was to concentrate on the provision of resources, management processes and functions necessary for the school to achieve its goals. The duties and responsibilities of today's school principals, leadership, communication, group processes, program development, teaching and learning processes, performance evaluation is gathered under many different headings (Şişman \& Turan, 2004). The contemporary school has neither a complete mechanicbureaucratic structure nor a complete "loose structure". It is not possible to bind everything to a rule in the school, to specify subordinate-parent relations between the staff and to apply close supervision, thus expecting efficiency (Balc1, 2000). Excessive adherence to bureaucracy and hierarchy can cause the school administrator to fail to meet the expectations and needs of today's schools and to make it a passive condition that is solely responsible for doing what is said. However, today's organizations expect their employees to act with a high sense of organizational citizenship and take self-initiative, take personal initiative without instruction, which go beyond the expected role behaviors that set goals in line with the objectives of the organization (Frese, Kring, Soose \& Zempel, 1996). In other words, the roles and tasks that the manager has to perform, routine tasks go far beyond correspondence, formalities, bureaucratic work and procedures. It is inevitable for school administrators to take personal initiative to fulfill what is expected of them. School administrators are influenced by many factors in performing their roles. One of these factors is their perceptions. The concept that includes how the individual sees himself in relation to these roles is the concept of self (Güngör, 1989). While the perception of the individual about his / her personality and roles is within the scope of self concept, the degree of this perception is expressed with self-esteem. Individuals with high selfesteem approach events with the expectation of being successful and being well received. Individuals with positive evaluations rely on their own perceptions and judgments. They believe that they can solve their problems when they show effort. They are more effective and entrepreneurial in their social relationships. Individuals with low self-esteem do not trust themselves and are afraid to come up with different ideas. Their social relations are weak, and they are involved in communication with people rather than as listeners (Coopersmith, 1967). The school administrator has to examine the different factors affecting the school, regulate the school environment relations, and establish relationships with parents and interest groups of the society (Çelik, 2004). High level of social skills is very important for school administrators to be successful in social communication inside and outside the school. Therefore, school administrators can be expected to have high self-esteem. Because individuals with high selfesteem become more entrepreneurial, safer and more aggressive in their social relationships (Kuzgun, 2002). Self-esteem contributes to positive social behavior and mental health. Low self-esteem causes many social behavior problems and psychological disorders such as depression, suicidal tendency, eating disorders and anxiety disorders, aggression and substance use disorders (Mann, Hosman, Schaalma \& De Vries, 2004). Welch, Meideros and Tate (1982); school administrators experience constant stress due to their abstraction in the workplace, unscheduled activities due to the nature of the work, problematic human relations, limited powers and special positions (Akt. Dönmez \& Güven, 2001). Therefore, the high self-esteem of school principals can be one of the factors that make it easier for them to cope with stress. In this regard, school administrators can be expected to have high self-esteem. Because the school principal has to be the leader of the internal elements that will realize the aims of the school, keep the structure alive and protect the atmosphere (Bursalığlu, 1991). It can be said that personal initiative behavior is related to the level of self-esteem of the individual because of the behavior initiated and maintained by the individual himself. In other words, high self-esteem school administrators can be expected to contribute more to their organizations in taking personal initiatives. 


\section{Method}

In this study, which is aimed to reveal the relationship between school principals' self-esteem levels and taking personal initiative, relational screening model was used. Screening models are research approaches aiming to describe a situation that existed in the past or present (Karasar, 2008). The population of the study consists of 225 school principals working in official primary, secondary and high schools of the Ministry of National Education in Edirne city center, Keşan, Uzunköprü, İpsala, Havsa, Enez, Süloğlu, Meriç and Lalapaşa districts in the 2018-2019 academic year. In this research, the whole universe was not sampled. The scale was delivered to 210 school principals that were accessible within the scope of the research; After the incorrect, incomplete and sloppy fillings were removed from the returning scales, the 161 scale forms filled by the school principals were evaluated for data analysis. In this research, Aricak SelfEsteem Scale geliştiril developed by Arıcak (1999) and Kişisel Personal Initiative Measurement School Principal Form in School Principals tarafindan developed by Akın (2012) were used to measure the self-esteem levels of school administrators.

\section{Result and Discussion}

According to the research findings; When the mean scores of the students are taken into consideration, they perceive the school principals' self-esteem levels as high enough as "fully agree inda in terms of self-esteem, self-confidence, achievement and productivity, depressive affect and self-value, respectively. In this case, it can be said that school principals are sociable, social, extrovert, believing and trusting individuals.

It was seen that school principals' perceptions about self-esteem levels in selfsufficiency dimension differed according to their professional service periods. As a result of multiple comparisons made to identify the difference group; It was found that school principals with 31 years or more professional service period had higher self-sufficiency scores than school principals with 1-10 years, 11-20 years and 21-30 years professional service period.

In terms of achievement and productivity, the opinions of school principals about selfesteem levels differ significantly according to the type of settlement in which they work. As a result of the comparisons made to identify the difference group; it was found that school principals working in the village had lower achievement and productivity points than school principals working in the district center and provincial center.

Considering the averages of scores obtained, the school principals consider their opinions about taking personal initiative to be highly sufficient in terms of persistence, proactivity and self-initiation, from the highest to the lowest, respectively. It can be said that school principals do not hesitate to take personal initiative.

The level of personal initiative of the principals differed significantly according to their educational level in terms of persistence. It can be said that school principals who have graduate degree have higher persistence score than school principals who have graduate degree.

The level of personal initiative of school principals varies significantly in terms of proactivity according to their age. School principals aged 51 and older had higher proactivity scores than school principals aged 21-30, 31-40 and 41-50.

The opinions of school principals about personal initiative differed significantly in terms of proactivity and persistence according to the type of settlement where the institution they work in. In the proactivity dimension of taking personal initiative of school principals working in the village; It was observed that they had lower scores than the school principals working in the district, district center and provincial center, and the school principals working in the district and provincial center.

In the study, it was found that there was a moderate positive relationship between the self-esteem levels of school principals and their personal initiative. As the self-esteem of the school principals increased, the status of taking personal initiative increased.

While the most important predictor of proactivity and persistence is self-confidence, the most important predictor of spontaneous start-up is achievement and productivity. In addition, it is seen that proactive behavior, which means being prepared for the problems and opportunities 
that may be encountered while implementing long-term goals, and persistence, which means not to give up the search for opportunities to overcome the problems and opportunities, are fed from self-esteem which means to attach a value to its own characteristics and to approve itself through these values. 